\title{
The Plight of the Firstborn in Genesis: Implications for Africa
}

\author{
Gerald Emem Umoren \\ Department of Religious and Cultural Studies \\ University of Uyo \\ Nigeria
}

\begin{abstract}
The first born - especially the first son - is given prime place in Africa and much is expected of him in the furtherance of patrimony. Even with its attendant problems, it is culturally unacceptable, in Africa, to transfer primogeniture to another sibling unless in case of death. This is why the plight of Biblical firstborns like Cain, Ishmael, Esau, Reuben and Manasseh, puzzles the African mind. This research employs a combination of exegetical, descriptive and analytical methods to examine the implications of this Biblical provision and draw lessons there from. The results and findings provide an objective appreciation of primogeniture for any people, and promise to be rewarding both for Biblical scholarship and for socio-cultural harmony especially in Africa.
\end{abstract}

Keywords: Firstborn, Patrimony, Primogeniture, Genesis, Africa

\section{Introduction}

Every Christian sees the Bible not just as Scripture but as Divine Revelation. The Bible contains the word of God - adjudged to be alive and active. When, in the Old Testament and especially in the Book of Genesis, we are consistently confronted with a scenario where almost all the firstborn sons ended up as a failure in spite of the age-long traditional provision for the prominence of the firstborn son, one is bound to ask questions. Such questions fearfully increase and yearn for answers considering a physical background like mine in Africa, where the firstborn occupies a pronounced place and whose role is culturally upheld to be sensitively sacrosanct and important. How much has the Biblical provision influenced - or better put - how much can the Biblical provision influence the cultural appreciation of the firstborn in Africa today? Is there any correlation between the Bible and the African understanding of firstborn today? Is it a blessing or a curse to be the firstborn? Is the firstborn always bound to fail? Can we draw any implications for one from the other?

These are some of the concerns that have occasioned this study. Progressing with the assumption that the Biblical provision could contribute to the cultural debate on the place of the firstborn in Africa, the aim of this work includes: To study selected Biblical passages in Genesis which address the firstborn; To interpret those passages against the Biblical theology of firstborn; ${ }^{1}$ To examine the real cultural value of firstborn in Africa; To seek understanding of the correlation between the Biblical position of firstborn and its cultural appreciation in Africa; To discover implications, make recommendations and draw relevant conclusions for socio-cultural harmony. This work employs the methods of Biblical exegesis in studying the major passages about firstborn in Genesis. The Descriptive and Analytical methods are also used to facilitate the exposition and correlation of the Biblical and African positions about the firstborn towards desired objective interpretation and application of its Biblical theology.

The scope of this work, in principle, covers the whole of the Book of Genesis on one hand and the entire continent of Africa on the other. However, for proper appreciation, there is the necessary delimitation of both points of views. Though there are more passages that address the idea of firstborn in Genesis, we would intentionally limit ourselves to the five that directly reflect the generational patriarchy of the Old Testament people. ${ }^{2}$

\footnotetext{
${ }^{1}$ For more on the nature of Biblical Theology especially in the book of Genesis, see Roland Faley, From Genesis to Apocalypse, New York: Paulist, 2005, pp. 1ff.

${ }^{2}$ For more on the generational patriarchy of the Old Testament people see, B. W., Anderson, Understanding the Old Testament, New Jersey: Prentice-Hall, 1966, pp. 1ff.
} 
These would include those of Cain and Abel (Gen. 4); Ishmael and Isaac (Gen. 16, 17, 21: 1-24); Esau and Jacob (Gen. 25: 21-34; 27: 1-46); Reuben and Joseph (Gen. 35: 22; 48: 21-22; 49: 1-28); and, Manasseh and Ephraim (Gen. 48: 13-20). On the other hand, we have delimited the African continent to the Annang Tribe, which is an ethnic group in Akwa Ibom State of Nigeria in Africa. Though limited by time, resources and sources of information about the African understanding of firstborn, this work has progressed successfully and has proved to be very relevant today in the ongoing debate about the firstborn. It is significant in its results, which address the needed restoration of the spirit of responsibility in the family and the larger society today.

\section{Explication of Terms}

For proper appreciation of the discourse in this work, it is important to explain the meaning and contextual usages of some of the key terms involved here. The major ones include, Firstborn, Genesis, and Africa.

\section{Firstborn}

The word 'firstborn' is the most widely referred to in the course of this work. Etymologically, it comes from the בכר Hebrew root (bkr), which generally connotes something coming 'early.' It is from this understanding that the idea of firstborn is developed from בכר. In Semitic language, firstborn is used generally of people and animals, and plants that open the womb of men and animals or mature first as fruits of plants. Here in this work, firstborn is used in many related ways. Basically referring to the firstborn son, it is used literally to mean the first to open the womb, metaphorically to refer to whoever takes up this role of the firstborn, and technically to mean the very rights and privileges of inheritance associated with the person seen as firstborn. Closely associated with firstborn is the idea of birthright, which in most cases guarantees inheritance. All these nuances are interwoven in our contextual usage of firstborn in this work, which primarily evokes the idea of the role and the person playing such role of responsibility following from his birthright or acquired prime position in the family or larger society.

The use of firstborn in this work is predicated on the fact that the eldest son's special position is recognized both in the Bible and in the cultural setting of today's Africa.

\section{Genesis}

Genesis is the first book of the Pentateuch, which is the first section of the Old Testament. ${ }^{3}$ Incidentally, it is the first book of the Christian Bible. Genesis is used here as a nominal reference source of the Biblical discourse on firstborn. Generally, the entire Bible - Old and New Testaments - does not only have a peculiar discourse on firstborn but it also has what could be called a Biblical theology of firstborn. ${ }^{4}$ The Bible has a 'worldview' in reference to firstborn. Delimiting this scope for proper examination brought us narrower from the entire Bible to the Old Testament and specifically to the Book of Genesis. As noted earlier, even in this Book of Genesis, it is not the entire 50 chapters that will be studied. Only five basically generational instances, which address the idea of firstborn, are considered for study in the name of the entire book. These passages, which are all found in the Book of Genesis, are those that talk about the first born in relation to Cain and Abel; Ishmael and Isaac; Esau and Jacob; Reuben and Joseph; and Manasseh and Ephraim. ${ }^{5}$ In this work, reference to Genesis is as a focus part within a whole. Each of those passages and all of those passages lay claim to the Book of Genesis as source and so reference to and use of Genesis in this work must be understood both in the broad sense as referencing the entire Biblical position and in the strict sense as covering the firstborn discourse in the Book of Genesis.

\section{Africa}

Africa, covering most of the land south of the Mediterranean, is known to be the world's second largest and second most populous continent in the world. It has about 54 sovereign States one of which is Nigeria, which is also the most populated of all the countries in the continent. Like many other places in the world, Africa has a lot of social and cultural values.

\footnotetext{
${ }^{3}$ See Gerald Emem Umoren, The Experience of the Israelite Exiles in Psalm 137 Compared with the Displaced Persons in Nigeria today: A Presentist Interpretation of the Bible, New York: Edwin Mellen, 2017, p. 3.

${ }^{4}$ By Biblical theology of firstborn here, we mean that the entire Bible has a basic theological understanding of firstborn such that every other part or section of it draws from it if when it refers to firstborn.

${ }^{5}$ Apart from the fact that these selections represent major patriarchal generations, these passages are found spanning from as early as the $4^{\text {th }}$ Chapter of the Book of Genesis to as late as the $49^{\text {th }}$ Chapter of the 50 Chapters in the entire book. This spread further explains why reference is generally made to the Book of Genesis.
} 
One of the many unique socio-cultural values in Africa is its appreciation of the 'firstborn cult. ${ }^{6}$ Given the practical impossibility of covering the entire continent to appreciate her take on the place of the firstborn, Africa the continent is delimited to a country, Nigeria, which is further delimited to Annang Tribe - a prominent, culturerich ethnic group in Akwa Ibom State of Nigeria. ${ }^{7}$ Though Africa will be used frequently in this work, it must be understood that the values projected for examination are basically from the Annang background and worldview.

\section{Biblical Appreciation of the Firstborn in the Book of Genesis}

The Biblical appreciation of the firstborn in the Book of Genesis cannot but begin with a background understanding of the first born in the entire Bible. But even before we consider the Bible, it is important to note that there are some extra Biblical references to the firstborn dating as early as civilization. In the Ancient Near East, the position of the firstborn was already held in high esteem before Biblical times. This esteemed position and accompanying privileges of the firstborn are reflected in the firstborn passages of the Bible where the Old Testament discourse becomes a prefiguration of the meaning and understanding of firstborn in the New Testament. This confirms that there is a Biblical theology of the firstborn. From the Old Testament, it is clear that the firstborn was regarded as the beginning of his father's strength, cf. Gen. 49:3; Deut. 21:17; $c f$. Ps. 78:51; 105:36; and the opener of the mother's womb, cf. Ex. 13:2, 12, 15; Num. 18:15; etc. Though reference is made to both father and mother, the emphasis on firstborn in the Bible is more on the father's side. It is more paternal than maternal. This explains why the status of firstborn was also accorded to Israel (Ex. 4:22) and the Davidic line (Ps. 89:27).

Generally, in the Old Testament, the first born has many privileges which included a larger inheritance, a special paternal blessing, family leadership and an honored place at mealtimes (Gen. 25:5-6; 27:35-36; 37:21ff.; 42:37; 43:33; Deut. 21:15-17). The Old Testament also talks of a double inheritance for the firstborn - cf. Deut. 21:1517. ${ }^{8}$ It is interesting to see that sometimes, in some circumstances and for certain reasons, some of these privileges can be lost, forfeited or overruled ${ }^{9}$ and often, it would shift to the younger or even the youngest of the siblings. These are the passages, especially in Genesis, which call for deeper study to enable us appreciate their meaning and import.

\section{Identifying the Texts}

The major texts here are:

1. Genesis 4, 5: 1-10 (The story of Cain, Abel and Seth - where Seth was favored over Cain, the natural firstborn)

2. Genesis 16, 17 and 21: 1-24 (The story of Ishmael and Isaac - where Isaac was favored over Ishmael, the natural firstborn)

3. Genesis $25: 21-34 ; 27: 1-46$ (The story of Esau and Jacob - where Jacob was favored over Esau, the natural firstborn)

4. Genesis 35: 22; 48; 21-22; 49: 1-28; (The story of Reuben and Joseph - where Joseph, the last born, was favored over Reuben, the natural firstborn)

5. Genesis 48: 13-20 (The story of Manasseh and Ephraim - where Ephraim was favored over Manasseh, the natural firstborn)

For want of space, we would always paraphrase the basic message contained in the entire chapter(s) of each of these five texts since the passages are long. We would present here, in Hebrew and in English, only those parts of the passage necessary for exegesis in this work.

\footnotetext{
${ }^{6}$ Reference to the appreciation of the firstborn in Africa as a cult is my creation. It is just and only a cultural value but I make reference to it as a 'cult' just to highlight the sensitivity which the people attach to its provision in the entire continent.

${ }^{7}$ Annang is the second largest ethnic group in Akwa Ibom State in the southeastern part of Nigeria.

${ }^{8}$ The Patriarchs do not seem to have a clear reference to the double share of the firstborn but it is mentioned in several Old Babylonian, Middle Assyrian and Nuzi documents, and it is alluded-to elsewhere in the Old Testament. See more in 2 Ki. 2:9 and Is. 61:7

${ }^{9}$ These privileges could normally be forfeited only by committing a serious offence. This can be seen in the cases referred to in Gen. 35:22; 49:4; 1 Chron. 5:1-2. It can also be lost by sale as in Gen. 25:29-34. Another way of loss of the privilege of the firstborn was through paternal preference of another other than the natural firstborn. Such instances manifested when the patriarchs would give a special blessing to one other than the firstborn son.
} 


\section{TEXT ONE: Genesis 4, 5: 1-10}

Genesis chapter four details the birth, life and sacrifice of Cain and Abel. It goes further to detail how Cain killed Abel and how this murder displeased God and attracted His punishment for Cain. After beginning a short genealogy of the fleeing Cain, to whom God showed mercy, this chapter significantly introduces the birth of Seth, a new son to Adam after the loss of Abel. The rest of Gen 5: 1-10 is a detailed genealogy of Seth which comparatively gives the impression that God's favour was more on Seth than the murderer, Cain. The plight of Cain is shown in Chapter 5 where this detailed genealogy does not mention his name at all but mentions Seth immediately after Adam.

\section{TEXT TWO: Genesis 16, 17, 21: 1-24}

Gen. 16 details the circumstances of the birth of Ishmael by Sarai's maid, Hagar, to Abram when he was 86 years old. Gen 17 details the covenant that God made with Abram to multiply him exceedingly. It extended to his wife Sarai and would be established in Isaac their future son. This chapter also introduces the circumstances of the birth of this Isaac and how God's covenant was to be established, not with Ishmael - the natural firstborn - as requested by Abram, but with Isaac. The passages of Gen. 17: 17-22 are very significant because they point to the shift of divine favor from Ishmael to Isaac. Chapter 21 details the birth of Isaac and, especially the circumstances narrated in verses 9-12, confirm God's position favoring Isaac over Ishmael who was the natural firstborn. The main passages necessary for our exegesis of the issue of firstborn here would be Gen. 17: 17-22 and 21: 9-12. They would confirm not only that Ishmael was the first to be born but also that God insisted His Covenant would be established with Isaac.

\section{TEXT THREE: Genesis 25: 21-34; 27: 1-46}

Genesis Chapter 25: 21-34 details the birth of children to Isaac. The circumstances of the birth of Esau and Jacob already point to the imminent twist in the role of the firstborn. Verses 21-26 talk of the birth of Isaac's children. In verse 23, God already prepared the mind of Rebekah, the mother, that "the elder shall serve the younger." Also verses 27 to 34 show how Esau himself sold his birthright - saying in verse 32, "of what use is a birthright for me?'

Chapter 27 addresses the circumstances in which Jacob deceived Isaac and took the blessing of Esau the natural firstborn. It is clear from Isaac's blessing of Jacob in Gen. 27: 28-29 and his later blessing for Esau in Gen. 27: 39-40 that the Old Testament firstborn twist was again in place. These passages are the most central of the five. Gen. 27: 41-46 details the enmity that ensued between Esau and Jacob on account of this twist in who actually enjoys the privileges of the firstborn. Given its centrality and for the purpose of close exegesis of the firstborn twist between Esau and Jacob, we would project Gen. 25: 21-34 and Gen. 27: 28-40

HEBREW

Gen. 25: 21-34

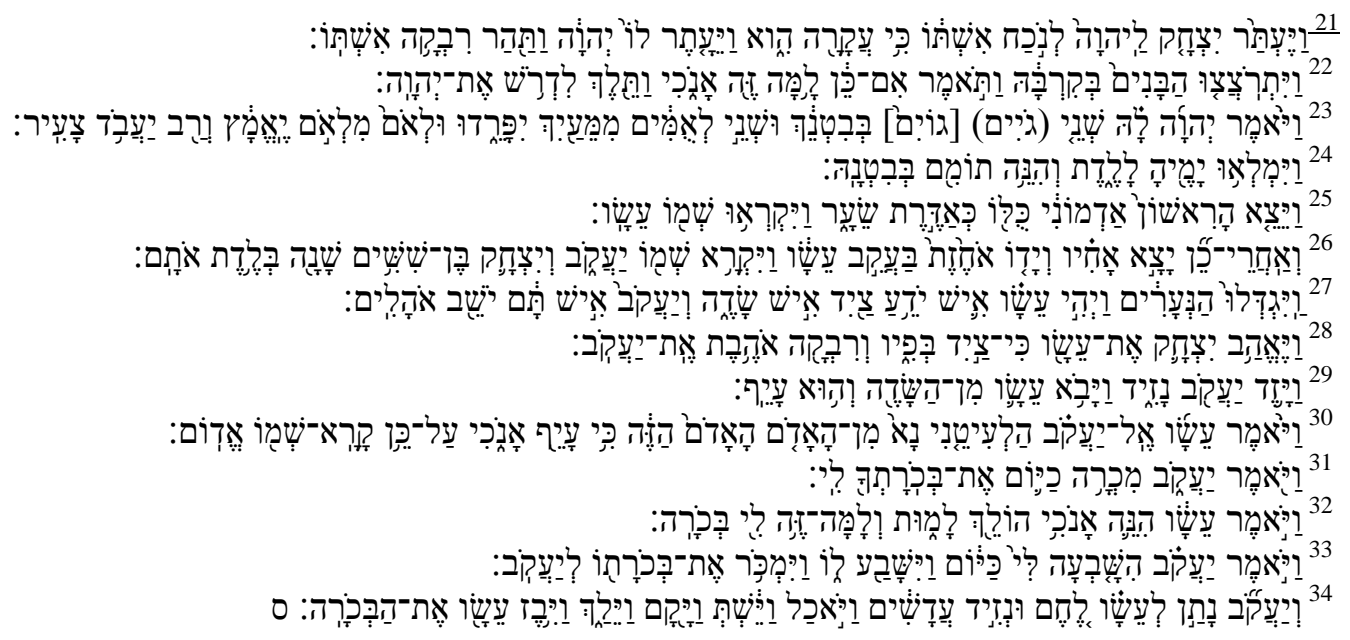

Gen. 27: 28-40 


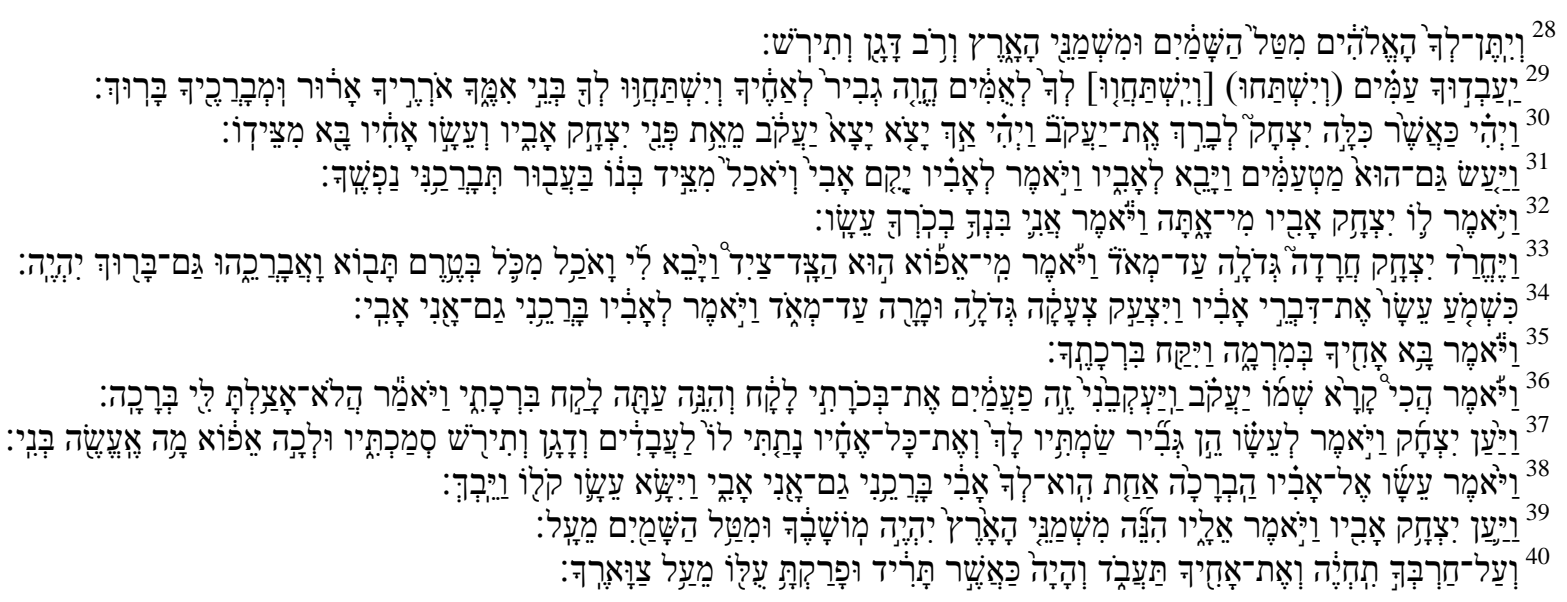

\section{English}

Gen. 25: 21-34

21 Isaac prayed to the LORD for his wife, because she was barren; and the LORD granted his prayer, and his wife Rebekah conceived.

22 The children struggled together within her; and she said, "If it is to be this way, why do I live?"1 So she went to inquire of the LORD.

23 And the LORD said to her, "Two nations are in your womb, and two peoples born of you shall be divided; the one shall be stronger than the other, the elder shall serve the younger."

24 When her time to give birth was at hand, there were twins in her womb.

25 The first came out red, all his body like a hairy mantle; so they named him Esau.

26 Afterward his brother came out, with his hand gripping Esau's heel; so he was named Jacob.1 Isaac was sixty years old when she bore them.

27 When the boys grew up, Esau was a skillful hunter, a man of the field, while Jacob was a quiet man, living in tents.

28 Isaac loved Esau, because he was fond of game; but Rebekah loved Jacob.

29 Once when Jacob was cooking a stew, Esau came in from the field, and he was famished.

30 Esau said to Jacob, "Let me eat some of that red stuff, for I am famished!" (Therefore he was called Edom.1)

31 Jacob said, "First sell me your birthright."

32 Esau said, "I am about to die; of what use is a birthright to me?"

33 Jacob said, "Swear to me first."1 So he swore to him, and sold his birthright to Jacob.

34 Then Jacob gave Esau bread and lentil stew, and he ate and drank, and rose and went his way. Thus Esau despised his birthright.

Gen. 27: $28-40$

28 May God give you of the dew of heaven, and of the fatness of the earth, and plenty of grain and wine.

29 Let peoples serve you, and nations bow down to you. Be lord over your brothers, and may your mother's sons bow down to you. Cursed be everyone who curses you, and blessed be everyone who blesses you!"

30 As soon as Isaac had finished blessing Jacob, when Jacob had scarcely gone out from the presence of his father Isaac, his brother Esau came in from his hunting.

31 He also prepared savory food, and brought it to his father. And he said to his father, "Let my father sit up and eat of his son's game, so that you may bless me."

32 His father Isaac said to him, "Who are you?" He answered, "I am your firstborn son, Esau."

33 Then Isaac trembled violently, and said, "Who was it then that hunted game and brought it to me, and I ate it all1 before you came, and I have blessed him? -- yes, and blessed he shall be!"

34 When Esau heard his father's words, he cried out with an exceedingly great and bitter cry, and said to his father, "Bless me, me also, father!"

35 But he said, "Your brother came deceitfully, and he has taken away your blessing." 
36 Esau said, "Is he not rightly named Jacob? I For he has supplanted me these two times. He took away my birthright; and look, now he has taken away my blessing." Then he said, "Have you not reserved a blessing for me?"

37 Isaac answered Esau, "I have already made him your lord, and I have given him all his brothers as servants, and with grain and wine I have sustained him. What then can I do for you, my son?"

38 Esau said to his father, "Have you only one blessing, father? Bless me, me also, father!" And Esau lifted up his voice and wept.

39 Then his father Isaac answered him: "See, away froml the fatness of the earth shall your home be, and away from 2 the dew of heaven on high.

40 By your sword you shall live, and you shall serve your brother; but when you break loose, 1 you shall break his yoke from your neck."

\section{TEXT FOUR: Genesis 35: 22-29; 49: 1-28}

Genesis 35: 22-29 does not only mention how Reuben committed incest with Bilhah, his father's concubine to the utter displeasure of Jacob, his father, but also, the genealogy of the house of Jacob here serves to prove that Reuben was the natural firstborn of Jacob and it shows the natural position of each of Jacob's children in the family. The whole Chapter 49 clearly details the blessings that Jacob gave to his sons. It shows clearly the blessings received by Reuben who is acknowledged as the firstborn and the elaborate blessings for Joseph - the lastborn - who appears to be favored in this twist. The major passages needed for the exegesis of the firstborn twist in the case of Reuben and Joseph would be: Gen. 35: 22-29 and Gen. 49: 1-4; 22-27. However, Genesis 48: 22 shows that Joseph was given a double share of portion - a right ordinarily reserved to the firstborn.

\section{TEXT FIVE: Genesis 48: 13-20}

This passage details how the Old Testament firstborn twist continued in the children of Joseph - Manasseh and Ephraim. It narrates how Ephraim, instead of the natural firstborn, Manasseh, was blessed with prominence notwithstanding the preference of Joseph the father. The entire passage is relevant for study on the firstborn twist.

\section{Analysis of the Texts}

Given the fact that this study is on different passages seen to be addressing a common theme, the best way forward in this analysis is to identify the areas of similarities in them and, may be, also look at the possible differences. There is a lot that the five passages share in common as far as the plight of the firstborn is concerned in the Book of Genesis. Some of these include:

$>$ They all address the same subject matter - the plight of the firstborn son

$>$ There is a twist in the plight of the firstborn in all the passages

$>$ In all of them, the natural firstborn loses something (Birthright, Blessing, Double portion,)

$>$ There is little or no appeal, nor any insistence to reverse trend in almost all of them.

$>$ There is some persistence by God or the patriarch-ancestor (explicitly or implicitly) to enforce the 'twist' as a foregone conclusion

$>$ In all the cases - with or without appeal, the design of God or that of the patriarch-ancestor prevails

The noticeable differences also include:

$>$ The levels of exchange differ. In some the loss is from the first to the second born (Ishmael to Isaac: Esau to Jacob; Manasseh to Ephraim). In others it is from the first to the third born (Cain to Seth) while in others it is from the firstborn to the lastborn (Reuben to Joseph).

$>$ The cause of the loss is not uniform. In some it is seen as divine design (Ishmael). In some, it is presumed to be a consequence of the firstborn's misbehavior (Cain and Reuben). In others it is the design of the patriarchancestor as expressed in his blessing (Manasseh). Still in others, it is as a result of a combination of greed, personal loss of self worth, deceit and eventual irrevocability of ancestral blessing (Esau)

$>$ The factor of blessing, though could be presumed, is not significantly explicit and prominent in all of them. While there is reference to blessing in the cases of Ishmael and Isaac; Esau and Jacob; Manasseh and Ephraim; Reuben and Joseph, there is no explicit reference to specific blessings in the cases of Cain and Seth

$>$ The reaction to save the twist is not uniform. In most of these instances, there is a light appeal to retain or regain the place, role and may be the inheritance of the natural firstborn (cf. Cain prays God for reduction in the gravity of his punishment Gen. 4: 13; Abraham argues for Ishmael - Gen. 17: 18-19; 
Esau pleads to be restored or at least to receive some blessing also - Gen. 27: 34; Joseph prays his father Jacob on behalf of Manasseh - Gen. 48: 17-19). However, in the case of Reuben, there is no known reference to any explicit appeal or reaction to the twist.

In all these similarities and differences, it is possible to identify some harmonious convergence in what the Book of Genesis records on the theme of the firstborn.

$\checkmark$ Notwithstanding the difference in levels, the common factor is that the Book of Genesis admits of what we may call the 'firstborn twist' where that natural firstborn almost always 'falls out of favor.'

$\checkmark$ Notwithstanding the cause of the loss, another common factor in Genesis is that the firstborn twist leads to a loss of some desired status with rights and responsibilities

$\checkmark$ Whether it is explicit or implicit, the blessings of God or that of the patriarch-ancestor is a significant common factor in the determination of who truly takes up the responsibility of firstborn.

$\checkmark$ Notwithstanding any reaction or non to save the twist, once initiated and sealed with the blessings, the firstborn twist is irrevocable

$\checkmark$ That taking a closer look at all the five passages together, it is possible to see that the passage referencing the birthright twist between Esau and Jacob - Genesis 25: 21-34; 27: 1-46 - accommodates almost all the similarities and differences noticeable in the remaining four passages and can therefore serve as a common reference to firstborn in the Book of Genesis.

For proper appreciation of this plight of the firstborn as reflected in these passages of the Book of Genesis, it is important to take a closer look at the passages concerned. ${ }^{10}$ The textual criticism of these passages reveals little or no tensions. For the purpose of our analysis, we are considering the passages as they appear in their final form. ${ }^{11}$ These passages, as projected above, include: Genesis 4, 5: 1-10 (The story of Cain, Abel and Seth - where Seth was favored over Cain, the natural firstborn); Genesis 16, 17 and 21: 1-24 (The story of Ishmael and Isaac where Isaac was favored over Ishmael, the natural firstborn); Genesis 25: 21-34; 27: 1-46 (The story of Esau and Jacob - where Jacob was favored over Esau, the natural firstborn); Genesis 35: 22; 48; 21-22; 49: 1-28 (The story of Reuben and Joseph - where Joseph, the last born, was favored over Reuben, the natural firstborn); Genesis 48: 13-20 (The story of Manasseh and Ephraim - where Ephraim was favored over Manasseh, the natural firstborn). These passages cut across all the section of the Book of Genesis ${ }^{12}$ and the consistency in the unfolding trend of events - a son that opens the womb for one reason or the other falls out of favor and his blessing and consequent birthright goes to a junior sibling who assumes primal responsibility in the family - confirms that the narrative, and what it points to, actually enjoyed the approval of the major sources at work in the compilation of the work. There is need and reason to narrow all these passages down to Genesis 25: 21-34; 27: 1-46 (The narrative of the twist between Esau and Jacob) because those represent the trend attested to in the other four passages. ${ }^{13}$ This will make it possible to analyze the story line structurally. By way of structural analysis, one can see a quadruple movement in the entire narrative, which could be referred to as the RIGHT; The PLIGHT and The FIGHT and the MIGHT.

THE RIGHT: Gen. 25: 21-26 (cf. verse 25) Here one can recognize the right of the firstborn attained through natural birth.

THE PLIGHT: Gen. 25: 27-34; 27: 1-29 (cf. 25: 32)

\footnotetext{
${ }^{10}$ There is a storyline in the book of Genesis and the different sections work together to enrich the theology of this story. This fact is well brought in Terence E. Frethrem, "The Book of Genesis: Introduction, Commentary and Reflection" in The New Interpreter's Bible Vol. 1, Ed. By Leander E. Keck et al, Abingdon, Nashville, 1994; and in Richard Clifford and Roland Murphy, "Genesis" in The New Jerome Biblical Commentary, Edited by Raymond Brown et al, Prentice Hall, NJ, 1990.

${ }^{11}$ This position is not to deny the role of different interventions at various stages of the compilation of the Book of Genesis. But for the purpose of Biblical Theology to be achieved, there is need to give the passages in question a synchronic analysis

${ }^{12}$ Conventionally and for scholarship purposes, the book of Genesis is divided into four sections. The pre-history covering Gen. 1-11; The Abrahamic generation covering Gen. 12-25; The Generation of Isaac covering Gen. 25-35 and finally the Generation of Jacob covering Gen. 35 to 50. The selected passages referencing the firstborn twist in Genesis cut across all these sections of the book.

${ }^{13}$ We would henceforth project Genesis $25: 21-34 ; 27: 1-46$ as a prototype passage for the rest of the passages referencing the firstborn twist in the Book of Genesis.
}

120 
Here, for various reasons, the natural firstborn has an unfavorable plight - There is a twist and he loses his birthright $^{14}$

THE FIGHT: Gen. 27: 32-41 (cf. verse 41) Here, the displeasure caused by the plight of the natural firstborn almost generates into enmity.

THE MIGHT: Gen. 27: 42 - 28:1 (cf. 28:1) On account of the blessing now given to the younger, the twist stands and firstborn responsibility reverses and is confirmed.

Since Genesis 25: 21-34; 27: 1-46 (The story of Esau and Jacob - where Jacob was favored over Esau, the natural firstborn) contains, as nucleus, all the facts of the scenario of firstborn twist, a closer and detailed analysis of these passages, would reveal more about the firstborn discourse in the book of Genesis. The educated guess of this research is that the firstborn discourse in Genesis addresses leadership. Apart from natural right of the firstborn from birth, it seems that personal responsibility plays a role here in the eventual emergence of one to take up the responsibility of firstborn. The irresponsibility of Cain and Reuben; the ambitious circumstances surrounding Ishmael and the self-abasement and meanness of Esau can be interpreted as factors/qualities not consistent with the demands of the role of the firstborn. Even the total silence of Manasseh over his plight suggests some weakness that is equally inconsistent with leadership. ${ }^{15}$ The twist seems to favor the future roles to be taken up by these people. ${ }^{16}$ Esau clearly shows his inability to lead when he declared in Gen. 25: 32 "I am about to die; of what use is a birthright to me?" The verb מוּת used here shows readiness to extinguish.

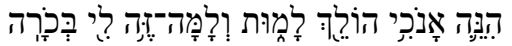

But a birthright was necessary to be able to take up the role of the firstborn and by so saying, Esau lost out even before the brother Jacob deceived him to receive the blessing and finally deprived him of the place of firstborn, cf. Gen 25:34. This meanness is the first sign of irresponsibility of Esau. ${ }^{17}$

Again, in the firstborn discourse in Genesis, the place of blessing is significant. In all the passages under review especially in the case of Jacob in Gen. 27: 28ff, the blessing from the patriarch-ancestor has remained a significant factor. ${ }^{18}$ There is a mandate of superiority and leadership, which is communicated in the blessings. ${ }^{19}$ God looked with favor on the offering of Cain; God blessed Isaac in Gen. 26: 24; Isaac blessed Jacob in Gen. 49: 28; Jacob blessed Ephraim in Gen. 48: 20; Joseph is set apart from his brother for blessings. In each of these cases, the blessing propels the person to prominence and responsibility. It must be noted that, in some cases, the natural first born is also blessed. But even in this situation, one can easily still discern the uniqueness of the blessings of the preferred firstborn figure or the prominence given to him. In place of Abel, Seth, a preferred firstborn figure is the main person recognized as the heir in the genealogy documented in Gen 5: 1ff. That showed Seth's preference and consequent prominence while Cain, the natural first born is not projected. In the case of Isaac and Ishmael, though Ishmael is also blessed, it is Isaac that is preferred and projected as the firstborn figure with whom the covenant with Abraham will be established (cf. Gen 17: 20-12). The particle conjunction (?) introducing the direct

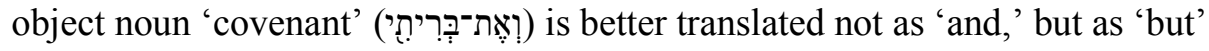

(As for Ishmael, I have heard you; I will bless him and make him fruitful and exceedingly numerous; he shall be the father of twelve princes, and I will make him a great nation. But my covenant I will establish with Isaac,

\footnotetext{
${ }^{14}$ For more on the loss of birthright by Esau see Alter's commentary in Robert Alter, Genesis: Translation and Commentary, Norton, NY, 1996, p. 129

${ }^{15}$ The Book of Genesis contains obvious reasons that were pointers to the disqualification of the natural firstborn. For example, it can be argued that right from the point of sacrifice, Abel showed more responsibility that Cain. Misery is not a good quality for a leader to have. As if that was not enough, he went further to murder his brother. Reuben had no selfcontrol and went into his father's wife. Esau had already disqualified himself when he sold his birthright over a bowl of red stew. One can only imagine what would have been the plight of the house of Abraham if Hagar's Ishmael were the child of covenant. Manasseh's silence proved him to be too weak for the role of the firstborn.

${ }^{16}$ Even consequent actions and reactions of Cain after he killed his brother Abel shows that he was not the type that would accept responsibilities. When asked by God, where is your brother, he answered, "I do not know." This can be seen as a denial of responsibility. For more on how the actions and reactions of Cain point to irresponsibility, see M. Kessler and K, Deurloo, A Commentary on Genesis - The Book of Beginning, New York: Paulist, 2004. Pp. 60-70.

${ }^{17}$ Cf. P. F. Ellis, The Men and the Message of the Old Testament, New York: Liturgical Press, 1962, p. 85.

${ }^{18}$ The blessing in this context is a kind of vitality that was imparted either directly by God or it was passed on by one departing from life.

${ }^{19}$ Some of this authority and mandate communicated in the blessing are implicit. Only a few of them are explicit.
} 
whom Sarah shall bear to you at this season next year. $)^{20}$ It shows that there is a departure from one position to another. ${ }^{21}$ Very significantly too, this is also seen in the case of Esau and Jacob. Esau is no doubt given some blessings but the significant blessing and consequent projection to prominence is that of Jacob. ${ }^{22}$ The same particle conjunction (?) is used again connoting a departure and therefore better translated 'but...' The twist makes it clear in verse 40 that he, Esau - the natural firstborn, would have to serve Jacob his younger brother, the projected firstborn figure. Though differing in explicitness, the same trend goes on in the case of Reuben and Joseph; and in that of Manasseh and Ephraim.

It is significant to see that no natural firstborn is cursed just because another person has been chosen and blessed. Though there is a preference for another firstborn figure different from the natural firstborn, there is never a place where the natural firstborn is cursed, destroyed or eliminated in order to make absolute room for the preferred firstborn figure. If anybody is punished, it is for earlier offence and not just to deny him grace or bring him down from being the active firstborn. Instead, what we see is some sort of blessing and also even the punishment of Cain was revisited and God gave him a seal lest someone would kill him. Ishmael was not cursed; Esau was not cursed; Reuben even with the incest he committed was not cursed and Manasseh was not cursed. So it is not as if there was a predesigned curse for the firstborn. ${ }^{23}$ A detailed analysis of these firstborn passages in the Book of Genesis confirms that the twist in the firstborn role is a plot to project the importance of responsibility in service.

\section{Interpretation of the Texts: The Plight of the Firstborn in Genesis}

The Old Testament has a story line. It details the history of a people whom God chose for Himself. ${ }^{24}$ The Book of Genesis records the beginning of this history from a theological point of view. ${ }^{25}$ From every indication, sustenance of this history with good and responsible direction was a concern and it was not enough for the Book of Genesis to key into the age-long provision of primogeniture, ${ }^{26}$ it was also very important for it to project a firstborn figure that would prove worthy of the inheritance and worthy of the demands of proper direction of God's covenanted people. The need to retain one who would ensure the responsible continuity of that covenanted history may have been the brain behind the twist in the firstborn discourse of the Book of Genesis.

Using the case of Esau and Jacob as a reference, the personality of Esau, as one who would not even treasure his status was going to be dangerous for the future responsibility of a patriarch-ancestor. The compiler of the Book of Genesis, in his plot projected a seemingly more dutiful and conscientious person - Jacob to occupy that position and serve the need of leadership. ${ }^{27}$ It is this Jacob, this new preferred firstborn figure, who eventually became the father of Israel. By plight of the firstborn, therefore, we mean the regrettable twist in the projection of the firstborn figure; where the natural firstborn almost always ends up a 'failure' and another firstborn figure is preferred in his place. But considering the possible reason for this plight, discernible from the circumstances, it is possible to appreciate the understanding that the plight of the firstborn in Genesis confirms that the firstborn is a vocation and must be understood, approached, pursued and appreciated as such.

\footnotetext{
${ }^{20}$ Gen. 17: 20-21 (Emphasis, mine)

${ }^{21}$ In this case, the departure was from favoring the natural firstborn - Ishmael to a preferred firstborn figure - Isaac.

${ }^{22}$ See Gen 27: 34-40

${ }^{23}$ See more on this point by reading Ezechiel "Zeke," Bamnolo, Jr., The Firstborn Son: A Curse, A Gift, or A Calling. Indianapolis, IN: Dog Ear, 2001, pp. ff.

${ }^{24}$ For more on the meaning, purpose and theology of the Old Testament, see: B. W., Anderson, Understanding the Old Testament, New Jersey: Prentice-Hall, 1966, pp. 1ff; P. F. Ellis, The Men and the Message of the Old Testament, New York: Liturgical Press, 1962. Pp. 1ff; R. Menezes, The Old Testament for Our Times, Mumbai: India, 2003, pp.1. ff; and R. W. L. Moberly, Old Testament Theology, Grand Rapids: Baker, 2013, pp. 1ff.

${ }^{25}$ See R. W. L. Moberly, Old Testament Theology, Grand Rapids: Baker, 2013, pp. 8ff.

${ }^{26}$ Even before the book of Genesis was compiled, Ancient Near East had a cultural value of primogeniture (The role and right of the firstborn gained through birth and blessing). Seen broadly, the Old Testament came to follow this as a provision for succession and responsible leadership of God's people. This conferred certain rights on this person primarily dedicated to God. Such rights included: Inheriting the father's role; Receiving a double share of the fathers property and generally Assuming the father's authority and responsibility;

${ }^{27}$ The way and manner Jacob readily responded to the plot of the mother to deceive his father and receive his brother's blessing shows his (Jacob's) ability to respond to tasks unlike Esau who presented an attitude of lack of zeal.
} 


\section{Traditional Appreciation of the Firstborn in Today's Africa}

It is true that the firstborn can be understood and appreciated in many ways depending on cultural or traditional settings. In Africa, as a cultural value, the firstborn is seen as an 'institution.' One common thing about the firstborn in Africa is that it is held as a prominent institution of succession and continuity of family line. The peculiar interpretation of this value could vary from place to place and circumstance to circumstance. In order to better appreciate the traditional understanding of firstborn in today's Africa, we would approach it from three points of views: The Place of the Firstborn in Primogeniture-focused Africa; The Rights and Privileges of the Firstborn and; The Vocation of the Firstborn: A Call to Responsibility

\section{The Place of the Firstborn in Primogeniture-focused Africa}

As earlier noted, in order to arrive at a detailed treatment of the African understanding of firstborn, we would delimit our scope to the Annang Tribe in Akwa Ibom State of Nigeria. ${ }^{28}$ Annang Tribe, like most of Africa, is basically patriarchal and believes in the sustenance of the family lineage. When firstborn is mentioned in Annang, it is both for the male and the female but emphasis is laid more on the firstborn son (AKPAN) than on the firstborn daughter (ADIAHA). In Annang Tribe as in typical African cultural setting, the first son is not only very much valued but the parents are very fond of him. He holds a special position in the parents' lives. Infact it is the value of the first son that gives meaning to the 'cult of the firstborn.' The right of the firstborn to inherit the headship of the family, carrying with it certain property rights and usually such titles as those of the family head or the family custodian is a common phenomenon in Annang Tribe as in every African community. Primogeniture has been part and parcel of the Annang world-view from the earliest times. ${ }^{29}$ The firstborn son in Annang is much more than first among equals. No matter how disadvantaged he may be or look; no matter how less privileged he may be or look, no matter how incapacitated he may be or look, as long as he was the first to open the womb he retains an enviable place in the family life and history. The position of the firstborn in Africa is that of honor and respect; right and privileges; that of responsibility and leadership and that of inheritance and custody.

The place of the firstborn in Africa is not transferable. In fact it is an abomination to try to abandon, sell or abscond from the natural birthright of the firstborn. The place of the firstborn is therefore never given over or taken over by another other than the natural firstborn. There are only two basic circumstances during which the place and consequently the role of the firstborn in Annang Tribe as in the rest of Africa may shift to another other than the natural first born. The ordinary and commonest situation is when the natural firstborn dies. In that case, the next elderly sibling assumes responsibility of the firstborn. He is never allowed to call himself the firstborn unless with some qualifying adjectives. ${ }^{30}$ The second circumstance during which the place of the firstborn can change is rare and dependent upon a lot of cultural factors and conditions; and it is not even very widely accepted. That happens when and where, at the instance and with the consent of the natural first born, in the occasion of serious sickness, incapacity or assumption of a ministry that demands detachment or distancing from family. In that case, he is seen as physically not being 'alive' to the family. In such a case, another sibling is nominated only by him, understood, and allowed to act on behalf of the natural first born. He is bound to consult the natural firstborn and must be disposed to take instructions from him. ${ }^{31}$ The place of the firstborn in Africa is therefore naturally sacrosanct, and, as an institution, it is culturally non-transferable with a lot of rights and privileges. It is important to analyze these rights and privileges of the firstborn in Annang Tribe of Africa and from there examine the call to responsibility.

\footnotetext{
${ }^{28}$ In this understanding, the words Annang would be used and understood interchangeably with Africa as most of what applies in continent is given better appreciation in the smaller tribes like the Annang Tribe.

${ }^{29}$ By Primogeniture here we mean both the state of being the firstborn and the exclusive right of inheritance which belongs to the eldest son

${ }^{30}$ Note that there is a marked difference between the firstborn and the eldest in the family. In the African patriarchal family system, by firstborn is meant the firstborn son. Even where a woman is the first to open the womb of the mother before other boy-children, the conventional reference to first born would not be to the eldest child (the woman) but to the first male even if he comes later or last. Also, in the event of the death of the natural firstborn son, the next elderly sibling that takes over cannot be truly addressed as the first born but can be qualified as "Akpan ukenge" meaning circumstantial first-son

${ }^{31}$ In this case, the natural firstborn is still the recognized custodian of the birthright. He appoints the person to act on his behalf but in consultation with/of him. He (the natural firstborn) is allowed, if circumstances allow and permit, to retrieve his responsibility at anytime.
} 


\section{The Rights and Privileges of the Firstborn}

Primogeniture necessarily presupposes rights and privileges in Africa. The use of the words 'rights' and 'privileges' is not to introduce any division or dichotomy. It only depends on the point of view. For the firstborn, it is a privilege since it is a natural status. ${ }^{32}$ But from the point of view of the community looking at what status this prime position at birth imparts, it is a 'right' as it gives the firstborn the unrivaled moral and legal authority and entitlement to perform certain unique functions.

In Africa, the rights and privileges of the firstborn would include the following:

1. Succession (Heir to the Cultural Institution/Stool)

2. Inheritance (Property, Assets and Liabilities)

3. Leadership (Familial Headship)

4. Decision (Rules on the course of events in the family)

5. Sustenance (Providing for the family)

6. Protection (He is the solace-figure)

7. Teaching (He sets moral standards)

Many firstborn children in Africa have these rights that go with responsibilities. They are expected to fit into the positions of their fathers in the family and in the social circle. Technically, they inherit everything the father has and it is then their responsibility to share it to the siblings, in most cases, at their goodwill. This authority, which he has over the younger siblings, is wielded in many ways. He gives the ladies out in marriage and decides and plans the future of the male siblings especially in the case of the death of the parent. They are left with the burden of supporting their families almost always but especially in the event where there is no parent, one parent or poor parents who cannot support the family meaningfully. In this way they are seen as surrogate parents. All these call him to exemplary behavior so that he would not lead the siblings astray.

\section{The Vocation of the Firstborn: A Call to Responsibility}

As it is generally understood, Rights go with responsibilities and the case is not different in Annang Tribe as in all parts of Africa. All the rights of the firstborn heap a huge bunch of responsibilities on him. In Africa, therefore, the right of the firstborn has become a vocation. It is a call to responsibility that eventually affects others within and without the nuclear family. These responsibilities are both for the present and for the future and the firstborn is called to feel in debt to his 'acquired constituency. ${ }^{33}$ In Annang Tribe, this responsibility is both expected and demanded of the firstborn. From the moment of birth, he is celebrated and followed up in preparation for this responsible role that he must assume. Fidel Nshombo, talking about the responsibility of the firstborn in Congo paints the same picture of what obtains here in the Annang Tribe of Nigeria.

It's a responsibility that no one would ever accept if proposed, but you can't choose when to be born. The first male child has to set rules and order in the family in the absence of the father. And after he grows, he has to provide and help his younger siblings to achieve their goals. Being the first born in the Congo means you can never screw up, never misbehave or be anything less than your father was. After you've grown, you'll be involved in every decision that the parents ought to make in the family. You'll be the one looked at whenever your younger siblings misbehave, and your parent will turn the disciplinary duties to you. Making sure everything around the family functions well and everybody represents the family values. ${ }^{34}$

Each of the rights of the firstborn comes with enormous responsibilities. It calls for self-discipline and sacrifices for the benefit of the family. This is why families struggle to educate and train their firstborn to be better equipped to carry out the functions associated with this state. It is all about selfless and sacrificial leadership meant to build the home.

\section{Evaluation}

\footnotetext{
${ }^{32}$ Being the firstborn is not on any human merit. It can only be understood as a privilege by whoever nature accords that 'honour.'

${ }^{33}$ For more about the present ad future debt of the firstborn, see Ezechiel "Zeke," Bambolo Jr., The Firstborn Son: A Curse, A Gift, or A Calling. P. 120-121

${ }^{34}$ Fidel Nshombo, "First Male Born and Responsibilities" in Boise Weekly, accessed on line on the $20^{\text {th }}$ July 2017 from www.boiseweekly.com. Posted on $21^{\text {st }}$ October 2009 
The study of the Book of Genesis ${ }^{35}$ and the passages which reference the firstborn discourse have revealed a number of facts about this theme especially in the Old Testament. The firstborn from every indication had an unfortunate turn of events in the passages studied. For whatever reasons, in a setting where primogeniture was not only recognized but respected, all the firstborn in the Biblical passages studied ended up a failure and went through the sad and humiliating experiences of witnessing their right and privileges taken from them and given to their younger siblings sometimes without adequate explanation. This really was an unfortunate plight. Also, outside the Bible and from a cultural point of view, it is equally found out that there is the traditional African appreciation of firstborn as an important value. Looking at the two, it is possible to decipher some similarities and differences and also find out why and what is happening where. The evaluation will attempt a comparative analysis of the understanding of firstborn in the two areas. We will try to identify possible implications for Africa and, based on the overall findings from the research, make some recommendations before we conclude.

\section{The plight of the Firstborn in Genesis vis-à-vis The Vocation of the Firstborn in Africa}

Against the background of the fact that the firstborn is generally a standard of leadership and continuity; and given the results of the findings above, one clear message in the book of Genesis is that the claim to birthright as a criterion for firstborn role was no longer sacrosanct. The call to exercise the duties of the firstborn was no longer dependent on birth-position but on responsibility delivery. It was no longer enough to be the natural firstborn. It became a call to responsibility that demanded and depended on pre-supposed blessing. That gave a different orientation to primogeniture in the Old Testament. This twist remained the plight of the natural firstborn. It is interesting too that the same mission goal that presupposed the twist of firstborn in the Old Testament is the same mission goal that the African cultural appreciation of firstborn is driving at. This mission goal is responsibility. It has to do with such responsibility that begins with the firstborn's self-discipline and self-sacrifice and goes further to the assumption of all the roles that would benefit the other members of the family who look up to him. Now, it is clear that these two agree in their mission goals. But while the plight of the Biblical firstborn is unfortunate because his status is never guaranteed, the plight of the African firstborn is fortunate because his status is not only guaranteed, but also almost irreversible.

We have seen and confirmed that the vocation of the firstborn in Africa is a call to responsibility. The extent of the need for that responsibility cannot be overemphasized. The big question is whether or not birthright alone can bestow responsibility and the answer is No. It is also seen that the possible reason for the twist in the firstborn role of the Book of Genesis was the need to ensure this responsibility. That is why the batten kept moving from the natural firstborn to the second born and sometimes, even to the last born. Since it is most improbable that birthright can bestow responsibility, it could therefore be safe to conclude that the need to look out for and "search for" a capable hand should be considered an important part of the firstborn discourse even in today's Africa. It is against the background of this understanding that the findings about the Biblical firstborn would have implications for and contributions to the conclusions of primogeniture in Africa

\section{Implications for Primogeniture-focal Africa}

The following would be the major implications of the Biblical firstborn lessons for Africa today. The spirit of the law of primogeniture should be taken into more consideration than the letters of that law. If Primogeniture is primarily not about the individual firstborn but about the leadership role that needs to be played in the family, then, Africa must reconsider its appreciation of the role in its cultural background. This implies that Africa must also begin to appreciate the wisdom of accepting a transfer of the role of firstborn to another sibling other than the natural firstborn especially in a situation where the natural firstborn does not seem or is not able to demonstrate the needed availability or responsibility demanded of that status. This would really call on Africa to reconsider a few things about the firstborn. The Natural firstborn could remain the leading figure but not necessarily the practical leader of the family. This position would also imply that the African natural firstborn be humble enough to accept that people could be differently endowed naturally and since these natural endowment do not come from position of natural birth, a junior sibling who proves to be responsibly endowed should be given the chance and the support to direct the affairs of the family.

\footnotetext{
${ }^{35}$ For more insight into the theology of Genesis and the theology in Genesis, also confer Nathan MacDonald; M. W. Eliott; Macaskill, Genesis and Christian Theology, Michigan, Eerdsman, 2014, pp. 1ff; R. Menezes, The Old Testament for Our Times, Mumbai: India. 2003, pp. 1ff; and R. W. L. Moberly, Old Testament Theology, Grand Rapids: Baker, 2013, pp. 9ff.
} 
This position would also imply that for Africa, decision to transfer actual leadership to a sibling other than the natural firstborn would no longer be a sole prerogative of the natural firstborn. More objectivity will now be needed by bringing in parents and/or other elders of the extended family to decide on, confirm, bless and enforce the choice of the preferred firstborn substitute and above all to facilitate collaboration and goodwill. More significantly, following the need to enforce the spirit of the law of primogeniture as communicated in the firstborn twist in the Old Testament, Africa must begin, not only to better appreciate the role of the firstborn girl in the family, but also to accommodate a situation - especially in the total absence of a male or even when and where such male is incapacitated and 'not alive' to the family- where the role of the practical firstborn could be played by a woman. Again, by implication of what we have said, sometimes she may not still be the first girl to open the womb and though all these have cultural implications for the typical African, there is need to re-orientate the African mind to accommodate these and other implications of the plight of the Biblical firstborn.

\section{Recommendations}

Based on the findings of this research work as seen above, and following the arguments proffered on the implications of Old Testament Biblical primogeniture for Africa, as seen in the book of Genesis, the following recommendations can be offered.

1. That the training of the natural firstborn and his preparation for responsible leadership be a communal responsibility of the extended family not just that of the nuclear family.

2. Those African parents would understand the need to allow their natural firstborn to begin to rise up to some responsibility in the family while they (parents) are still alive. In that way, responsibility and self-esteem could be cultivated, decisions and actions could be guided; mistakes could be corrected; abuses could be checked and incapacity could be identified earlier.

3. African parents should learn to write their will or communicate same while alive to avoid conflict after death

4. Apart from a greater share of inheritance still going to the natural firstborn, a separate share/portion of patrimony should be allocated as a 'general insurance' for the upkeep of the family and this is to be managed by the practical firstborn, be he the natural firstborn or a preferred firstborn-figure to whom the role is transferred.

5. Women should also be given their share of the father's inheritance

\section{Conclusion}

Having come this far in our research, it is clear that the debate about the place and role of the firstborn is not only wide spread - having Biblical and extra Biblical attestations, but it is also clear that it is very important and meaningful to draw lessons from it for the socio-cultural relevance of primogeniture in Africa. Our findings have confirmed that primogeniture generally allows several privileges for the firstborn. While the privileges in the Old Testament would include double inheritance, blessing, family leadership, honored place at meals etc, the extra Biblical privileges would include near inviolability, immunity, much attention and much honor. All these privileges were for a reason. Whoever had the right by birth to these privileges was expected to prove responsible. The twist, which characterized the firstborn position in the Book of Genesis, was in search of this responsibility. The need to project and implant a responsible figure for the crucial task of leading the people occasioned the twist. Apart from other circumstances that could be explained as God's overall design to give responsible leadership to His people, most of the natural firstborn lost their position out of their own fault - a glowing indication of the lack of the needed charismatic leadership quality. Cain killed his brother, Esau sold his birthright, Reuben committed incest and for different other reason, paternal preference may have been a factor.

Further findings have shown that, Africa, like many other places, also attaches much importance to primogeniture and the value attached to the firstborn is in expectation of the responsibility he is supposed to carry. But given that the African appreciation of the firstborn rests permanently on the natural firstborn, and on realizing that the natural firstborn may not always be - and indeed has not always been - up to the responsibility, it became necessary, as a fruit of our research, to highlight the implications, make recommendation and now draw conclusions that the place of the firstborn is basically a vocation to responsibility and family leadership and that the plight of the firstborn in Genesis, characterized by the constant twist, was actually a plot to challenge irresponsibility and reject mediocrity. On account of the above, this research has led to further conclusion for Africa, which, by culture does not normally accommodate any forfeiture of the firstborn role in the family. 
Since primogeniture is basically for responsibility and since birthright alone cannot always bestow this value of responsibility, it is imperative on today's Africa to pay attention to this trend and rethink its appreciation of firstborn to accommodate, appreciate and understand possible flexibility in the provision of that service for the family. There is no doubt that this reorientation would come with its challenges but if followed in Africa, it would usher-in a better socio-cultural platform for appreciating primogeniture in Africa.

\section{Works Cited}

Alter, Robert, (1996), Genesis: Translation and Commentary, Norton, NY.

Anderson, B. W., (1996), Understanding the Old Testament, New Jersey: Prentice-Hall.

Bambolo, Jr., Ezechiel (2001), "Zeke,” The Firstborn Son: A Curse, A Gift, or A Calling. Indianapolis, IN: Dog Ear.

Bangsund, James C., (1994), "The Consolation of the Firstborn in Genesis: A Lesson for Christian Mission" in Word and Word No.14, Vol. 2 St. Paul, MN: Luther Seminary series.

BIBLE WORKS 9, (2013), Norfolk, VA: Bibleworks LLC.

Clifford, Richard and Murphy, Roland, (1990), "Genesis" in The New Jerome Biblical Commentary, Edited by Raymond Brown et al, Prentice Hall, NJ.

Ellis, P. F., (1962), The Men and the Message of the Old Testament, New York: Liturgical Press.

Hamilton, Victor P., (1995), "The Book of Genesis, Chapters 18-50" in The New International Commentary on the Old Testament, Grand Rapids, MI: Eerdmans, Grand Rapids.

Faley, Roland, (2005), From Genesis to Apocalypse, New York: Paulist.

Frethem, Terence, E., (1994), "The Book of Genesis: Introduction, Commentary and Reflection" in The New Interpreter's Bible Vol. 1, Ed. By Leander E. Keck et al, Abingdon, Nashville.

Kessler, M. and Deurloo, K, (2004), A Commentary on Genesis - The Book of Beginning, New York: Paulist.

Kizhakkeyil, Sebastian, (2013), The Pentateuch: An Exegetical Commentary, Mumbai: India.

MacDonald, Nathan; Eliott, M. W.; Macaskill, (2014), Genesis and Christian Theology, Michigan, Eerdsman.

Menezes, R., (2003), The Old Testament for Our Times, Mumbai: India.

Moberly, R. W. L., (2013), Old Testament Theology, Grand Rapids: Baker.

Nshombo, Fidel, (2009), "First Male Born and Responsibilities" in Boise Weekly, accessed on line on the $20^{\text {th }}$ July 2017 from www.boiseweekly.com.

Olukoya, D. K.,(2017), Life in Christ, The Battle of Christian Ministries, USA.

Umoren, Gerald Emem, (2017)The Experience of the Israelite Exiles in Psalm 137 Compared with the Displaced Persons in Nigeria today: A Presentist Interpretation of the Bible, New York: Edwin Mellen. 